DOI: 10.15290/bsp.2016.20A.en.03

\author{
Elżbieta Kużelewska \\ University of Białystok \\ ekuzelewska@gmail.com
}

\title{
Compulsory Voting in Belgium. A Few Remarks on Mandatory Voting
}

\begin{abstract}
Democracy is not possible without the participation of citizens in politics. One of the duties required of citizens for development of democracy is the selection of representatives to parliament. Belgium is one of several European countries with compulsory voting. The Belgian compulsory voting system is the oldest and the most stable in the world. Although views on mandatory voting are split, it remains in use and non-participation in elections is sanctioned. The aim of the article is to analyze compulsory voting in Belgium, identifying the reasons for its introduction and discussing the ongoing debate in that country on whether the practice should be maintained or abolished.
\end{abstract}

Keywords: elections, compulsory voting, Belgium

Słowa kluczowe: wybory, przymus wyborczy, Belgia

\section{Introducing the term compulsory voting}

Mandatory voting (compulsory voting, obligatory voting) takes place in many countries in the world. Compulsory voting appears in two forms - as a political or a legal requirement. The first form is characteristic of non-democratic countries. The legal duty is present in those democratic countries where participation in elections is mandatory. Those democratic countries which decided to introduce mandatory voting did it in a bid to increase turnout in general elections. Compulsory voting is a legally binding voting rule, most commonly enshrined at a constitutional level ${ }^{1}$. It is understood as a requirement to participate in the elections, not the obligation to cast a vote. Despite its name, it carries no requirement to actually vote, just a requirement

1 G. Kryszeń, Przymus wyborczy, “Przegląd Sejmowy” 2004, No. 3(62), p. 63. 
to turn up and register at a polling station ${ }^{2}$. Moreover, compulsory voting does not imply the obligation to vote for one of the political parties. A voter may cast a vote (valid or not) at a polling station; they may also refuse to put the ballot paper in the box. According to Lijphart, compulsory voting means just the requirement to turn up at a polling station. Compulsory voting does not require stating a preference. Lijphart regards compulsory voting as less restrictive and onerous for citizens than many other legal requirements, for example the requirement to pay taxes, mandatory education or military service. Not voting means deriving advantages from democracy without personally contributing ${ }^{3}$.

Currently compulsory voting occurs in twenty-nine countries in the world ${ }^{4}$. The first countries (apart from Belgium) to introduce compulsory voting were: Liechtenstein (in 1862), Argentina (1914), Luxemburg (1919) and Australia (1924)5. Additionally, the United States have experimented with compulsory voting (Dakota 1898, Massachusetts 1918) ${ }^{6}$; Venezuela (in mid 1990s) and the Netherlands (1967) have both abolished compulsory voting. Currently compulsory voting exists in six western European countries: Belgium, Greece, Liechtenstein, Luxemburg, Switzerland (Schaffhausen canton ${ }^{7}$ ) and in Cyprus. Austria, Italy and the Netherlands have abolished it.

Non-participation results in more or less onerous sanctions. Compulsory voting (and potential sanctions for failing to take part in elections) directly influences turnout. All the twenty-nine countries where voting is compulsory have a high election turnout, approximately 10-15\% higher than the countries which have not introduced compulsory voting ${ }^{8}$.

Therefore there are two elements that comprise the term compulsory voting the requirement to vote and the sanctions for failing to do so. If a country does not penalise those who do not vote, then compulsory voting requires solely attendance at a polling station and failing to meet this requirement does not result in sanctions

2 A. Lever, Compulsory voting: a critical perspective, "British Journal of Political Science", March 2009, p. 3.

3 A. Lijphard, Unequal Participation: Democracy's Unresolved Dilemma, "American Political Science Review" 1997, vol. 91, No. 1, p. 10.

4 http://www.idea.int/vt/compulsory_voting.cfm (accessed on: 18.04.2014.).

5 M. Gratschew, Compulsory Voting in Western Europe, (in:) Voter Turnout in Western Europe, p. 25.

6 S. Jackman, Compulsory Voting, International Encyclopedia of the Social and Behavioral Sciences, p. 3.

7 A. Żukowski, Przymus wyborczy - istota, przesłanki i implikacje, "Prawo i Polityka" 2009, No. 1(1), p. 112.

8 International Institute for Democracy and Electoral Assistance (IDEA), http://www.idea.int/ (accessed on: 18.04.2014). 
being applied. In some countries only registered voters have a duty to vote. But the entry onto electoral register is not compulsory ${ }^{9}$.

In the case of Belgium, automatic voting may be a better tactic than compulsory voting. Voters are required to turn up at a polling station where they may return a blank ballot paper. Therefore 'abstaining from voting' does not have a special significance in the voting terminology in Belgium. The abstaining votes are regarded as empty or invalid votes. It's the turnout that matters.

This article aims to analyse compulsory voting in Belgium, showcasing the reasons for introducing mandatory voting and to familiarise the reader with the debate over maintaining or abolishing mandatory voting in that country.

\section{The evolution of elections legislation in Belgium}

Elections in Belgium were census based. In 1891 only $1 \%$ of the members of the society were eligible to vote (men over 25 years of age and paying land tax $)^{10}$. According to the 1830 elections regulations, voters voted in the seat of the authorities of their constituency. The distance from home, the timing of the elections, as well as lack of political awareness of part of the electorate were the reasons for declining election turnout ${ }^{11}$. The reformed Constitution of 1893 abolished the property requirement and introduced mandatory, multi-party elections. Men over 25 had two or three votes ${ }^{12}$. Fathers and landowners, as well as higher education diploma holders, were privileged in the number of votes they had. The changes were championed by three political parties: Partie ouvrier belge, Parti liberal and some of the democrats from the Parti catholique ${ }^{13}$. Between 1919-1948 only men were eligible to vote still, but all had only the one vote and the minimum age requirement was lowered to 21 . Mandatory voting was introduced in 1893. Each person on the electoral register is required to participate in elections ${ }^{14}$. Between 1948 and 1981 both men and women

9 M. Gratschew, Compulsory Voting..., op. cit., p. 26.

10 R. Jankowska, Głosowanie obowiązkowe a demokracja. Przykład Królestwa Belgii, (in:) S. Wróbel (ed.), Dyle- maty współczesnej demokracji, Toruń 2011, p. 321

11 Konstytucja Królestwa Belgii, Translation and introduction W. Skrzydło, Warszawa 2010, p. 11.

12 A. Głowacki, System konstytucyjny Belgii, Warszawa 1997, p. 7.

13 J.-B. Pilet, Choosing compulsory voting in Belgium: strategies and ideas combined, http://ecpr. eu/Filestore/Pa- perProposal/53cb7c8c-38e0-4a02-8cdc-47d70494182f.pdf, 2007, (accessed on: 20.04.2014) pp. 3-4.

14 Art. 105-107 the Electoral Code of Belgium of $12^{\text {th }}$ April 1894 [Code Lectoral de 12 avril 1894], Interieur 15.04.1894, $\mathrm{nr}$ 1894041255, p. 1121, http://www.ejustice. just.fgov.be/cgi_loi/loi_a1.pl?language=fr\&la=F\&c$\mathrm{n}=1894041230$ \&table name $=$ loi\&\&caller=list\&fromtab=loi\&tri=dd+AS+RANKLNK0001 (accessed on: 20.04.2014 .). 
over 21 could vote in general elections. The age requirement for both genders was reduced to 18 in $1981^{15}$.

Belgium was the first country in the world to have replaced the first-past-the post electoral system with proportional representation ${ }^{16}$. The principle of proportionality and confidentiality of elections was introduced into the Constitution in $1920^{17}$. Article 62 of the Belgian Constitution states unequivocally that voting is mandatory and secret ${ }^{18}$.

\section{The introduction of compulsory voting in Belgium}

Compulsory voting has been in existence in Belgium since $1893^{19}$ and extends to cover the elections to the European Parliament ${ }^{20}$. Belgium was the first country in the world where, the duty to vote extended nationally. Before that voting was mandatory in some Swiss cantons but not at a national scale ${ }^{21}$. Until 1893 voting was not compulsory in Belgium. An appropriate amendment was introduced in to the Belgian Constitution in order to for "the views and attitudes of the society to be as fully reflected as possible to enable the Parliament to be representative and secure strong democratic representation" 22 . Essentially, compulsory voting was introduced in order to popularise the idea of voting amongst uneducated parts of society and to prevent employers from denying the workers the right to vote by detaining them at work. Compulsory voting stemmed from a view that each citizen has a duty to take an interest in the matters of state, especially given the fact that in 1861 in Brussels

15 J. Stengert, Histoire de la législation électorale en Belgique, Revue belge de philologie et d'histoire. Tome 82 fasc. 1-2, 2004. Histoire medievale, moderne et contemporaine - Middeleeuwse. moderne en hedendaagse geschie- denis, p. 248.

16 M. Hooghe, K. Deschouwer, Veto Players and Electoral Reform in Belgium, "West European Politics", 2011, vol. 34(3), p. 628.

17 A. Młynarska-Sobaczewska, Prawo wyborcze do parlamentu Królestwa Belgii, (in:) S. Grabowska, K. Składowski (eds.), Prawo wyborcze do parlamentu w wybranych państwach europejskich, Kraków 2006, p. 80.

18 Konstytucja Królestwa Belgii..., op. cit.

19 J. Briggs, K.Celis, For or Against: Compulsory Voting in Britain and Belgium, "Social and Public Policy Review" 2010, 4(1), p. 2

20 P. van Aelst, J. Lefevere, Has Europe got anything to do with the European elections? A study on split-ticket voting in the Belgian regional and European elections of 2009, "European Union Politics" 2012, vol. 13(3), p. 8. The turnout in EP elections in Belgium in 1979-2014 had never fallen below 90\% - A. Muxel, Les enjeux. Des élec- tions européennes en manque délecteurs, mais une relative stabilisation de la participation, "SciencePO Juin" 2014, No. 4, p. 3, http://www. cevipof.com/rtefiles/File/ELECTIONS\%20EUROPEENNES/noteMUXEL.pdf (accessed on: 20.04.2014 r.).

21 J. Stengert, Histoire de la legislation..., op. cit., p. 268.

22 L. Żołądek, Przymus wyborczy. Geneza, praktyka funkcjonowania, argumenty za i przeciw, "Studia BAS" 2011, 3(27), p. 12. 
only $10 \%$ of those eligible to vote took part in elections ${ }^{23}$. In the general elections in 1843 the turnout was $14 \%{ }^{24}$. Low election turnout became the chief argument for the introduction of compulsory voting in Belgium. In Belgium, voting has been compulsory for all men since 1919 (the multiple vote system was replaced by the one man one vote system), and for all women since $1949^{25}$. The constitutional introduction of mandatory voting aimed to guarantee that all new voters - all male citizens of Belgium who had a vote - would turn out en-masse and contribute to the electoral success of the new socialist workers party ${ }^{26}$. The Liberal Party was not keen on the change and opted for the elections to be voluntary. One of its MPs - Charles Graux - has described the abstaining socialist voters as poor and unhappy social rejects, ignorant in political matters and incapable of informed voting ${ }^{27}$.

The second key argument for introducing mandatory voting was the desire to diminish the share of votes of radical parties. Catholic parties counted on an increase in the number of votes of their supporters, especially in rural areas. Paradoxically, the reasons for the victory of the ultra-right Vlaams Block in the 1991 elections were thought to lie in compulsory voting. Voters with a duty to vote expressed their frustration by voting for an extreme right-wing party. The logic of this argument holds to a degree. However, one needs to bear in mind that in the French speaking part of the country ${ }^{28}$ compulsory voting equally applies yet it has not resulted in the electoral victory of the extreme right-wing parties ${ }^{29}$.

Another argument for introducing compulsory voting was the desire to guarantee that political parties would not pay the potential opposition voters off for not voting in elections. At the time it was commonly acknowledged that elections in those times were corrupt (using money or a bottle of whisky) ${ }^{30}$. Political elites were convinced that introducing a duty to vote would reduce costs of an election campaign because compulsory voting would replace large expenditure related to encouraging voters to turn out and come to a polling station ${ }^{31}$. Until then the electoral candidates

23 A. Żukowski, Przymus wyborczy..., op. cit., p. 113.

24 M. Rachwał, Przymus wyborczy a legitymizacja władzy politycznej, "Studia Polityczne" 2012, No. 4, p. 236.

25 A. Żukowski, Przymus wyborczy..., op. cit., p. 114.

26 M. Hooghe, K. Deschouwer, Veto Players..., op. cit., p. 628.

27 A. Malkopolou, The History of Compulsory Voting in Europe. Democracy's Duty?, Routledge 2015, p. 1.

28 See more on language divisions in Belgium in e.g. : E. Kużelewska, "Language Border and Linguistic Legislation in Belgium", Michigan State International Law Review 2015, vol. 3(1), http://msuilr.org/?forum-conveniens=langu-age-border-and-linguistic-legislation-in-belgium (accessed on: 29.04.2014).

29 M. Hooghe, K. Deschouwer, Veto Players..., op. cit., p. 623.

30 J.C. Courtney, D. Wilby, Le débat sur le vote obligatoire, Revue parlamentaire canadienne/hiver 2007, p. 42, http://www.revparl.ca/30/4/30n4_07f_Courtney-Wilby.pdf (accessed on: 29.04.2014).

31 L. Żołądek, Przymus wyborczy..., op. cit., p. 12. 
would meet the voters travel costs and subsistence on the day of the elections, hence for example the legendary "d'Alost sausages" 32 . Elections took place in the capital. The introduction of compulsory voting would remove the financial burden from the shoulders of the politicians for a number of reasons, one of which was the fact that elections now took place in local authorities, without the need to travel to the capital. Compulsory voting introduced in 1893 was enforced with minimal sanctions ${ }^{33}$.

Each citizen who is entitled to vote is obliged to participate on the Election Day. Belgian citizens over 18 as well as those registered as residents in local authorities are automatically registered as voters ${ }^{34}$. Before the elections each registered voter receives a polling card together with a summons (lettre do convocation). Each person registered on the electoral roll in each local authority has the duty to participate in elections ${ }^{35}$. In parliamentary elections as well as in regional council and provincial elections a residency census is required - a voter must have been living in a given locality for the period of at least six months. This duty does not apply to certain categories of persons, for example those who have been legally declared as unable to vote, or those who are serving a custodial sentence longer than three months.

The situation of Belgian citizens living abroad is interesting. Since 1999 they are entitled to vote, however they are not automatically entered onto the electoral register $^{36}$. They are required to get registered at an embassy. They then get issued with a polling card and from then on, voting is compulsory for them. The same system includes non-Belgians living in Belgium. Compulsory voting concerns not just the citizens of that country but also foreigners who, without having Belgian citizenship, are registered on the electoral roll ${ }^{137}$ (this is the case only with European Parliamentary elections and local elections). Since $1999 \mathrm{EU}$ citizens living in Belgium have a right to vote in local elections ${ }^{38}$. The decision on whether to register on the electoral roll is theirs. If they decide to enter their names on the list of voters, voting becomes mandatory for them and carries the threat of sanctions for failing to participate. From 2004 onwards, the right to vote in local elections has been extended to all non-

32 J. Stengert, Histoire de la legislation..., op. cit., p. 268

33 R.B. Achour, Etat de la question. Pour ou contre le vote obligatoire?, Institut Emile Vandervelve 2010, p. 21, http:// www.iev.be/getattachment/04267ce6-9f77-4518-9bd5-b4b7d1bc174c/Pourou-contre-le-vote-obligatoire--.aspx (accessed on: 29.04.2014).

34 J.-B. Pilet, Choosing compulsory voting..., op. cit., p. 2.

35 Art. 105-107 of the Electoral Code of Belgium of 12 April 1894 [Code Lectoral de 12 avril 1894], Interieur 15.04.1894, no 1894041255, p. 1121, http://www.ejustice. just.fgov.be/cgi_loi/loi_a1.pl?language $=$ fr\&la=F\&c$\mathrm{n}=1894041230$ \&table name $=$ loi\&\&caller=list\&fromtab=loi\&tri=dd+AS+RANKLNK0001 (accessed on: 29.04.2014).

36 Loi du 18 décembre 1998.

37 L. Żołądek, Przymus wyborczy..., op. cit., p. 17.

38 Loi du 23 mars 1989 r. elative à l élection du parlement européen, art. 39; La loi du 27 janvier 1999 [Moniteur belge du 30 janvier 1999]. 
Belgian citizens who have been living in Belgium for at least five years ${ }^{39}$. Both these forms have encountered multiple difficulties along the way. There were fears over upsetting the linguistic balance in Brussels which is home to many Europeans and other non-Belgian citizens.

According to Belgian law, voters are required to turn up at a polling station and confirm their identity to the members of the electoral commission. They do not have to mark the ballot paper in any way.

\section{Sanctions for failing to vote}

Non-participation in elections carries the risk of sanctions as specified under Chapter VI of the Belgian Electoral Code w Art. 207-210 ${ }^{40}$ In the first years after compulsory voting was introduced in Belgium the sanction was a formal caution applied to those who failed to turn up at a polling station for the first time ${ }^{41}$.Voters who are unable to participate in voting present the magistrate with reasons for absence together with required proof. Within eight days of the results of the elections being declared, the crown prosecution drafted a list of voters who did not participate without a leave of absence. Those voters face criminal proceedings in court ${ }^{42}$. In Belgium the fine for failing to turn up on elections day for the first time is $€ 5$-€10 (the magistrate may increase it to $€ 30-€ 60$ ), for the second time $€ 10$ - $€ 25$ (and even $€ 60-€ 150)^{43}$. Voters who do not participate in elections and whose absence was not excused pays a fine without a right of appeal. If a voter fails to attend at least four times in 15 years they are struck off the electoral register for the period of 10 years and in that time they may receive no nomination or hold a public post ${ }^{44}$. This is a kind of restriction of citizens' rights and may be an effective deterrent as around $16 \%$ of Belgians are employed in the public sector ${ }^{45}$. However, it is worth stressing that Belgium allows vote by proxy as well as a postal vote ${ }^{46}$.

39 J.-B. Pilet, Choosing compulsory voting..., op. cit., s. 2; La loi du 19 mars de 2004 [Moniteur belge du 23 avril 2004].

40 The electoral code [Code electora] of $18^{\text {th }}$ April 1894, "Interieur" 1894.04.15, nr 1894041255, p. 1121, http://www.ejustice.just.fgov.be/cgi_loi/change_lg.pl?language=fr\&la=F\&c$\mathrm{n}=1894041230 \&$ table_name $=$ loi (accessed on: 29.04.2014).

41 S. Birch, Full participation. A comparative study of compulsory voting, United Nations University Press, 2009, p. 8.

42 A. Młynarska-Sobaczewska, Prawo wyborcze do parlamentu..., op. cit., p. 84.

43 Code électoral art. 209-210, http://www.elections.fgov.be/index.php?id=3300\&L=0 (accessed on: 06.05.2014 r.).

44 A. Młynarska-Sobaczewska, Prawo wyborcze do parlamentu..., op. cit., p. 84.

45 E. Lund, Compulsory voting: a possible cure for partisanship and apathy in U.S. politics, "Wisconsin International Law Journal", vol. 31(1), pp. 95-96.

46 E. Dydak, A. Saczuk, Królestwo Belgii, (in:) K.A. Wojtaszczyk, M. Poboży (eds.), Systemy polityczne państw Unii Europejskiej, Volume I, Warszawa 2013, p. 134. 
It is worth highlighting that statutory sanctions for failing to meet the electoral duty tend to stay on paper, with the exception of the fine. Since 2003 there have been no convictions for failing to participate in elections due to the fact that, because of the number of pressing cases, the crown prosecution has not filed any cases ${ }^{47}$.

Table 1. Electoral turnout in federal elections in Belgium 1981-2014

\begin{tabular}{|c|c|}
\hline Elections & Turnout (\%) \\
\hline 2014 & 89.45 \\
\hline 2010 & 89.22 \\
\hline 2007 & 91.08 \\
\hline 2003 & 91.63 \\
\hline 1999 & 90.53 \\
\hline 1995 & 91.10 \\
\hline 1987 & 93.40 \\
\hline 1985 & 93.59 \\
\hline 1981 & 94.60 \\
\hline
\end{tabular}

Source: own table.

Over the period of 30 years the elections turnout in Belgium has been maintained at a comparable, high level of around 90\%. Belgians' active participation is the result of their conviction that voting is their moral duty and their high citizenship awareness. A few days before the elections, the media publicise the duty to participate in elections, reminding voters of the sanctions for non-participation ${ }^{48}$. Despite a generally high turnout, the regional disparity between Wallonia and the Flanders is intriguing. The Belgian federal elections have noted that a quarter of the residents of Wallonia and Brussels were either absent or returned an invalid or empty ballot paper, whereas for the residents of Flanders that percentage was $15 \%{ }^{49}$.

\section{Discussions over abolishing compulsory voting in Belgium}

From the moment it was introduced until the 1970s compulsory voting was questioned by many. The questioning peaked in 1970 when the Netherlands abolished compulsory voting. At that time, first and foremost the Flemish started to re-consider

47 R.B. Achour, Etat de la question..., op. cit., pp. 21-22.

48 J.-B. Pilet, Choosing compulsory voting..., op. cit., p. 3.

49 G. Pion, Le vote blanc et nul en Wallonie: analyse écologique et individuelle, Belgeo (Revue Belge de Géographie): Miscellaneous 2010, No. 3, p. 249. 
their stance on elections and the idea to copy the Dutch idea became popular, especially with new regional parties. These parties were also behind the introduction of a referendum and direct mayoral elections in cities. In the early 1990s the Flemish liberals (PVV, now VLD) started the campaign to abolish mandatory voting. It was suggested that compulsory voting contributes directly to 'pathological' results of general elections, leading to difficulties in forming a federal government. The liberals valued more a single vote of an informed voter than those of passive citizens who participate in elections because they are legally required to do so. Those passive citizens are then able to impulsively vote for extremist parties, without subscribing to their ideologies in any way ${ }^{50}$.

For the Flemish Liberals obligatory voting is symptomatic of an over restrictive state and is at loggerheads with the principle of personal freedom. According to the VLD, nobody should be forced to elect their representatives if they don't want to. The right to vote should be regarded simply as a right, and citizens are free to enjoy their rights or not ${ }^{51}$.

With regards to the arguments over a potential violation of basic individual rights and liberties by mandatory voting this issue was probed in 1971 by the European Human Rights Commission (and, contrary to what is quoted in literature, settled by the European Human Rights Tribunal) ${ }^{52}$. Until 1998 individual complaints were brought before the Commission which, if a case was regarded as valid, would take up the applicant's petition in the European Human Rights Tribunal. Only the XI Protocol of 1994 (enacted in 1998) introduced the opportunity to lodge an individual complaint directly with the European Human Rights Tribunal. In 1971 the Commission declared the complaint of $X$ versus Austria as inadmissible. The Commission concluded that the use of compulsory voting does not constitute a breach in basic rights and liberties because the electoral duty remains unchanged, and in reality is a misnomer, especially in Western Europe. The Commission argued that many systems with compulsory voting do not require their citizens to vote but to participate in elections ${ }^{53}$. This participation, being present at a polling station is what is mandatory, not the act of voting. The Commission concluded that compulsory voting is not in breach of the right to the freedom of thought, conscience and religion (Art. 9 of the European Human Rights Convention) ${ }^{54}$. The Commission indicated that

50 A. Malkopolou, The History of Compulsory..., op. cit., p. 1-2.

51 L. de Winter, J. Ackaert, Compulsory Voting in Belgium: a Reply to Hooghe and Pelleriaux, "Electoral Studies", vol. 17 (4), p. 427.

52 B. Engelen, Why Compulsory Voting Can Enhance Democracy, Acta Politica 2007, No. 42, p. 30.

53 Decyzja Europejskiej Komisji Praw Człowieka w sprawie $X$ versus Austria, Application No. 4982/71, http://hudoc. echr.coe.int/sites/eng/pages/search.aspx?i=001-27952 (accessed on: 06.05.2014).

54 L. Baston, K. Ritchie, Turning out Or Turing off? An analysis of political disengagement and what can be done about it?, London 2014, http://electoral-reform.org.uk.downloadefile/turning-out- 
only the presence (participation) is mandatory; the voters are free to return empty or invalid ballot papers ${ }^{55}$. Proposals to abolish compulsory voting have started to appear in Belgium since the early 1990s. Any material changes do not, however, seem likely due to the fact that abolishing mandatory voting requires a constitutional reform. Amending the Constitution over this matter seems practically impossible due to the supermajority requirement of at least two thirds of the votes ${ }^{56}$. Moreover, unlike the leaders of the major liberal parties (e.g. the VLD), the Belgians are not interested in abolishing compulsory voting and regard it as an important issue meeting legislative requirements $s^{57}$.

Abolishing compulsory voting meets with the opposition of socialist party leaders who realise that in the event of compulsory voting being abolished they stand to lose voters and, consequently, parliamentary seats. Although the socialists are not significant veto-players in Parliament (due to a small number of seats) they would be unlikely to block the decision by themselves; however abolishing compulsory voting has never been officially included on the Parliametary agenda and put to the vote ${ }^{58}$. The Christian Democrats party's stand is close to that of the Socialists - they are not keen on the change proposed by the Liberals. The potential abolition of compulsory voting would serve to undermine the well-grounded and comfortable position of the Christian Democrats ${ }^{59}$. Liberal parties whose vote lies generally with the better educated and socially engaged voters, are not worried about electoral loses resulting from the potential abolition of compulsory voting.

The Liberals, realising the difficulties with amending the Constitution required to abolish compulsory voting, changed their strategy in 2008. One of the arguments for abolishing compulsory voting are the limited sanctions imposed on those for fail to fulfil their duty to vote. Those sanctions are too limited to be effective in persuading citizens to participate in the vote. This means that anybody failing to vote is almost certain that they won't be punished. The leader of the Liberal Party therefore proposed - maintaining the constitutional principle of mandatory voting - to abolish the provision of the electoral law (through the ordinary majority of votes) governing the sanctions for non-participation. Should the Liberals' plan succeed, they were hoping that voters would realise that, if mandatory voting is no longer enforceable, the adherence to the constitutional rule would slowly be relegated to the closet, as

or-turning-off-.pdf (accessed on: 06.05.2014), p. 36.

55 Europejska Konwencja Praw Człowieka, http://www.echr.coe.int/Documents/Convention_POL. pdf (accessed on: 06.05.2014).

56 Konstytucja Belgii z 1994 r., Tytuł VIII [Constitution of Belgium of 1994, Title VIII].

57 M. Hooghe, K. Deschouwer, Veto Players..., op. cit., p. 632.

58 M. Hooghe, K. Deschouwer, Veto Players..., op. cit., p. 632.

59 K. Deschouwer, Political Parties and Their Reactions to the Erosion of Voter Loyalty in Belgium: Caught in a Trap, (in:) P. Mair, W.C. Müller, F. Plasser (eds.), Political Parties and Electoral Change, Sage 2004, p. 202. 
was the case with other countries. The Liberals' proposal, like the others beforehand, was not debated in Parliament ${ }^{60}$.

In turn, the supporters of maintaining compulsory voting argue that the duty to vote guarantees that the citizens legitimise political institutions. Participation is the lifeblood of democracy ${ }^{61}$. Citizens are therefore required to actively express their will through voting. This was well illustrated by Flemish socialists who proclaimed that the duty to vote guarantees that the Parliament does not become a company where a small minority of wealthy shareholders wields power because the majority of shareholders are absent ${ }^{62}$. The Christian Democrats maintain that mandatory voting ensures that the least well educated citizens are integrated into a democratic system. They do not deny that those voters are, or were, politically ignorant. Ignorance in political matters resulted from the lack of familiarity. However, mandatory voting has allowed the lower social classes to become familiar with the electoral cycle, enabling them to learn how to vote and respect elections. It has also contributed to developing an interest in increasing their rights ${ }^{63}$.

Table 2. If compulsory voting was abolished in Belgium, would you vote in elections?

\begin{tabular}{|l|c|c|c|c|c|}
\hline & \multicolumn{5}{|c|}{ YEARS } \\
\hline Answers & 1991 & 1995 & 1999 & 2003 & $\begin{array}{c}\text { Average } \\
(\%)\end{array}$ \\
\hline Always & 34.9 & 43.1 & 47.4 & 41.8 & 41.8 \\
\hline Mostly & 12.1 & 14.3 & 14.9 & 14.8 & 14.0 \\
\hline Sometimes & 12.5 & 13.3 & 11.5 & 14.3 & 12.9 \\
\hline Never & 30.5 & 24.7 & 21.5 & 26.8 & 25.9 \\
\hline Don't know & 10.0 & 4.6 & 4.7 & 2.3 & 5.4 \\
\hline Total & 100 & 100 & 100 & 100 & 100 \\
\hline $\begin{array}{l}\text { Number of } \\
\text { respondents }\end{array}$ & 2691 & 3638 & 4229 & 2221 & \\
\hline
\end{tabular}

Source: Belgian Election Studies (ISPO) of 1991, 1995, 1999, 2003 (Billiet, Swyngedouw et al. 1991-2004). Data in the table as \%.

In light of the research aimed at assessing, through questionnaires, the possible negative impact of abolishing compulsory voting on elections turnout, $26.6 \%$ of Belgians have responded that they would not participate in elections when this was

60 M. Hooghe, K. Deschouwer, Veto Players..., op. cit., p. 633.

61 M.N. Franklin, Electoral Participation, (in:) L. Leduc, R.G. Niemi, P. Norris (eds.), Comparing Democracies: Elec- tions and Voting in Global Perspective, London 1996, p. 216.

62 J.-B. Pilet, Choosing compulsory voting..., op. cit., p. 9.

63 Malkopolou, The History of Compulsory..., op. cit., p. 2. 
no longer compulsory, and $13 \%$ of Belgian respondents would 'sometimes' take part $^{64}$. On the other hand, the data contained in the table optimistically indicate that over $50 \%$ of respondents would always or mostly take part in elections even after this was no longer compulsory. It is therefore feasible to propose that the attitude towards compulsory voting in Belgium is not that of resentment, but of respect. The Belgians treat voting as an important duty which they are obliged to perform as citizens of their country ${ }^{65}$. A potential abolition of compulsory voting would result in a drop in turnout, (but just over half would still participate in the vote) and a strong conviction that conservative parties would gain ${ }^{66}$.

Opponents of compulsory voting answer the arguments about an increased turnout by pointing at other methods. Apart from mandatory voting these include: making the election day a non-working day or a national holiday, introducing an automated registration, establishing polling stations in shopping centres, extending elections over two days or introducing other incentives ${ }^{67}$. The discussion includes voices saying that non-participation is also a form of political expression. Low turnout may simply mean the lack of voters satisfaction with political powers or be an expression of political apathy. According to the opponents of mandatory voting the electoral duty does not help legitimise those in government. Compulsory voting does affect a higher turnout but does not legitimise the government due to a relative large share of asinine votes, ${ }^{68}$ and invalid votes or protest votes.

The discussion taking place in Belgium over the need to change electoral law (in particular the proportional representation and the d'Hondt method, unaltered since their introduction in 1899) has included the necessity to maintain compulsory voting. Although some small modifications have been introduced into the Belgian electoral system, nevertheless these have not substantially affected the key dimension of the electoral process ${ }^{69}$. The majority of Belgians are for maintaining compulsory voting, arguing that this neutralises political polarisation. Should voting cease to be compulsory, the following voter profile would dominate: male, well educated, about 35 years of age $e^{70}$.

64 G. Kryszeń, Przymus wyborczy..., op. cit., p. 67.

65 E. Lund, Compulsory voting..., op. cit., pp. 97-98.

66 A. Lijphart, Thinking about democracy. Power sharing and majority rule in theory and practice, Routledge 2008, p. 205.

67 L. Hill, Compulsory voting in Australia: a basis for a 'best practice' regime, "Federal Law Review" 2004, vol. 32, p. 485.

68 G. Kryszeń, Standardy prawne wolnych wyborów parlamentarnych, Białystok 2007, p. 250.

69 M. Hooghe, K. Deschouwer, Veto Players..., op. cit., p. 628.

70 S. Marien, Is Compulsory Voting a Good Idea? The Consequences of Compulsory Voting in Belgium, PartiRep Research Network Brussels/Leuven 2007, pp. 8-9, M. Hooghe, K. Pelleriaux, Compulsory Voting in Belgium: an Application of the Lijphart Thesis, "Electoral Studies" 1998, vol. 17(4), pp. 421-423. 


\section{Conclusions}

Belgium is among 20 world countries with highest general elections turnout ${ }^{71}$. Compulsory voting is without a doubt one of the most effective means of increasing turnout in elections. Mandatory voting stimulates the government to simplify voting procedures (e.g. no need to register each time before elections or making the elections day a non-working day). Due to the fact that the electorate often do not realise that voting is in their own interest compulsory voting becomes a kind of guardian of democratic election rights. Mandatory voting moves the onus onto the citizens but the state compensates for this by introducing institutional cost saving solutions (like voting on non-working days or the ease to enter the electoral register). The sanctions are less vital. An important feature of compulsory voting is the fact that voting is perceived as a citizen's duty ${ }^{72}$. Compulsory voting in Belgium was introduced as an element of universal suffrage. It became not just one element in the legal-political system but a tradition or a habit. It represents a way of life where social norms are more important than sanctions. The consensus amongst Belgians is that voting is not just a right, it is a form of responsibility for the state. The Belgians turn out for the elections because this is part of participating in democracy.

The supporters of mandatory voting point out that the will of the electorate is better reflected in their chosen representatives in Parliament. The elections are a democratic duty of the citizens therefore compulsory voting increases the democratic level of elections and legitimacy of the elected authorities as well as successfully making the common voting right universal.

\section{BIBLIOGRAPHY}

Achour R.B., Etat de la question. Pour ou contre le vote obligatoire?, Institut Emile Vandervelve 2010, p. 21, http://www.iev.be/getattachment/04267ce6-9f77-4518-9bd5-b4b7d1bc174c/Pour-oucontre-le-vote-obligatoire--.aspx

Baston L., K. Ritchie, Turning out Or Turing off? An analysis of political disengagement and what can be done about it?, London 2014, http:electoral-reform.org.uk.downloadefile/turning-out-or-turning-off-.pdf

Birch S., Full participation. A comparative study of compulsory voting, United Nations ress, 2009 Briggs J., K. Celis, For or Against: Compulsory Voting in Britain and Belgium, Social and Public Policy Review 2010, 4(1)

de Winter L., J. Ackaert, Compulsory Voting in Belgium: a Reply to Hooghe and Pelleriaux, Electoral Studies, vol. 17 (4)

71 S. Marien, Is Compulsory Voting..., op. cit., p. 5.

72 S. Matsler, Notes. Compulsory Voting in America?, Southern California Law Review 2003, vol. 76, s. 966, http:// www-bcf.usc.edu/ usclrev/pdf/076404.pdf (accessed on: 10.05.2014). 
Deschouwer K., Political Parties and Their Reactions to the Erosion of Voter Loyalty in Belgium: Caught in a Trap, (in:) P. Mair, W.C. Müller, F. Plasser (eds.), Political Parties and Electoral Change, Sage 2004

Dydak E., A. Saczuk, Królestwo Belgii, w: K.A. Wojtaszczyk, M. Poboży (eds.), Systemy polityczne państw Unii Europejskiej, Warszawa 2013

Engelen B., Why Compulsory Voting Can Enhance Democracy, Acta Politica 2007, No. 42

Franklin M.N., Electoral Participation, (in:) L. Leduc, R.G. Niemi, P. Norris (eds.), Comparing Democracies: Elections and Voting in Global Perspective, London 1996

Głowacki A., System konstytucyjny Belgii, Warszawa 1997

Gratschew M., Compulsory Voting in Western Europe (in:) Voter Turnout in Western Europe

Hill L., Compulsory voting in Australia: a basis for a 'best practice' regime, Federal Law Review 2004, vol. 32

Hooghe M., K. Deschouwer, Veto Players and Electoral Reform in Belgium, West European Politics, 2011, vol. 34(3)

Hooghe M., K. Pelleriaux, Compulsory Voting in Belgium: an Application of the Lijphart Thesis, Electoral Studies 1998, vol. 17(4)

Jackman S., Compulsory Voting, International Encyclopedia of the Social and Behavioral Sciences Jankowska R., Głosowanie obowiązkowe a demokracja. Przykład Królestwa Belgii, (in:) S. Wróbel (ed.), Dylematy współczesnej demokracji, Toruń 2011

Konstytucja Królestwa Belgii, Tłumaczenie i wstęp. W. Skrzydło, Warszawa 2010 Kryszeń G., Przymus wyborczy, Przegląd Sejmowy 2004, No. 3(62)

Kryszeń G., Standardy prawne wolnych wyborów parlamentarnych, Białystok 2007

Kużelewska E., Language Border and Linguistic Legislation in Belgium, Michigan State International Law Review 2015, vol. 3, http://msuilr.org/?forum-conveniens=language-border-and-linguisticlegisla- tion-in-belgium

Lever A., Compulsory voting: a critical perspective, British Journal of Political Science, March 2009 Lijphard A., Unequal Participation: Democracy's Unresolved Dilemma, American Political Science Review 1997, vol. 91, No. 1

Lijphart A., Thinking about democracy. Power sharing and majority rule in theory and practice, Routledge 2008

Lund E., Compulsory voting: a possible cure for partisanship and apathy in U.S. politics, Wisconsin International Law Journal, vol. 31(1)

Malkopolou A., The History of Compulsory Voting in Europe. Democracy's Duty?, Routledge 2015 Marien S., Is Compulsory Voting a Good Idea? The Consequences of Compulsory Voting in Belgium, PartiRep Research Network Brussels/Leuven 2007

Matsler S., Notes. Compulsory Voting in America?, Southern California Law Review 2003, vol. 76, http://www-bcf.usc.edu/ usclrev/pdf/076404.pdf

Młynarska-Sobaczewska A., Prawo wyborcze do parlamentu Królestwa Belgii, (in:) S. Grabowska, K. Składowski (eds.), Prawo wyborcze do parlamentu w wybranych państwach europejskich, Zakamycze 2006 
Muxel A., Les enjeux. Des élections européennes en manque délecteurs, mais une relative stabilisation de la participation, SciencePO Juin 2014, No. 4, p. 3, http://www.cevipof.com/rtefiles/File/ ELECTIONS\%20EUROPEENNES/noteMUXEL.pdf

Pilet J.-B., Choosing compulsory voting in Belgium: strategies and ideas combined, http://ecpr.eu/Filestore/PaperProposal/53cb7c8c-38e0-4a02-8cdc-47d70494182f.pdf, 2007

Pion G., Le vote blanc et nul en Wallonie: analyse écologique et individuelle, Belgeo (Revue Belge de Géographie): Miscellaneous 2010, No. 3

Rachwał M., Przymus wyborczy a legitymizacja władzy politycznej, Studia Polityczne 2012, No. 4

Stengert J., Histoire de la législation électorale en Belgique, Revue belge de philologie et d'histoire. Tome 82 fasc. 1-2, 2004. Histoire medievale, moderne et contemporaine - Middeleeuwse. moderne en hedendaagse geschiedenis van Aelst P., J. Lefevere, Has Europe got anything to do with the European elections? A study on split-ticket voting in the Belgian regional and European elections of 2009, European Union Politics 2012, vol. 13(3)

Żołądek L., Przymus wyborczy. Geneza, praktyka funkcjonowania, argumenty za i przeciw, Studia BAS 2011,3 (27)

Żukowski A., Przymus wyborczy - istota, przesłanki i implikacje, Prawo i Polityka, 2009, No. 1(1) 